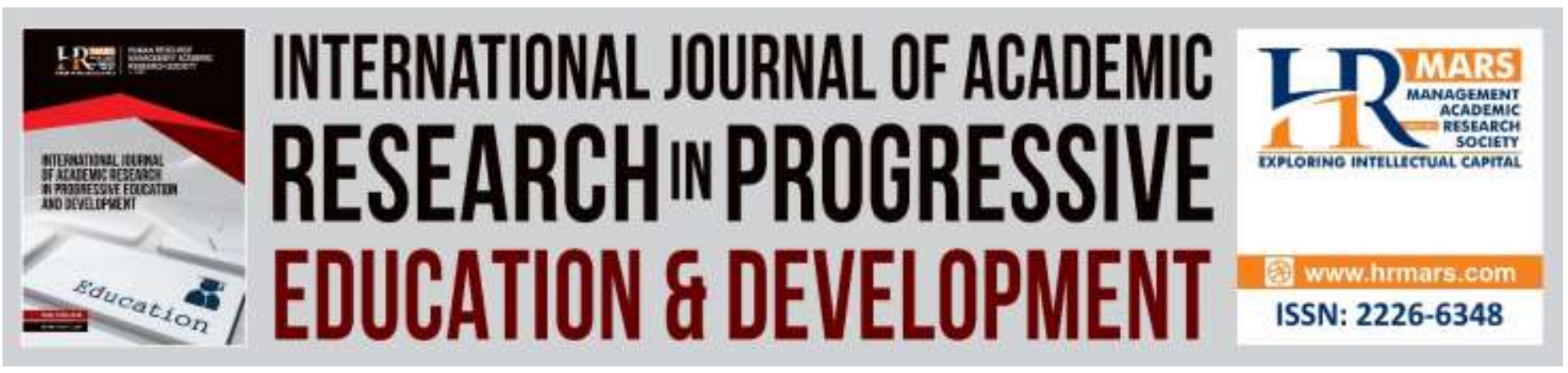

\title{
Analysis on KH. Fahmi Basya's Thoughts of Islamic Mathematics
}

Ferayanti, Rahimah Embong, Hanif Md Lateh, Firdaus Khairi Abdul Kadir

To Link this Article: http://dx.doi.org/10.6007/IJARPED/v8-i2/5767

DOI: $10.6007 /$ IJARPED/v8-i2/5767

Received: 30 March 2019, Revised: 20 May 2019, Accepted: 23 May 2019

Published Online: 23 May 2019

In-Text Citation: (Ferayanti, Embong, Lateh \& Kadir, 2019)

To Cite this Article: Ferayanti, Embong, R., Lateh, H. M., \& Kadir, F. K. A. (2019). Analysis on KH. Fahmi Basya's Thoughts of Islamic Mathematics. International Journal of Academic Research in Business and Social Sciences, 8(2), 249-256.

Copyright: (C) 2019 The Author(s)

Published by Human Resource Management Academic Research Society (www.hrmars.com)

This article is published under the Creative Commons Attribution (CC BY 4.0) license. Anyone may reproduce, distribute, translate and create derivative works of this article (for both commercial and non-commercial purposes), subject to full attribution to the original publication and authors. The full terms of this license may be seen

at: http://creativecommons.org/licences/by/4.0/legalcode

\section{Vol. 8(2) 2019, Pg. 249 - 256}

Full Terms \& Conditions of access and use can be found at http://hrmars.com/index.php/pages/detail/publication-ethics 


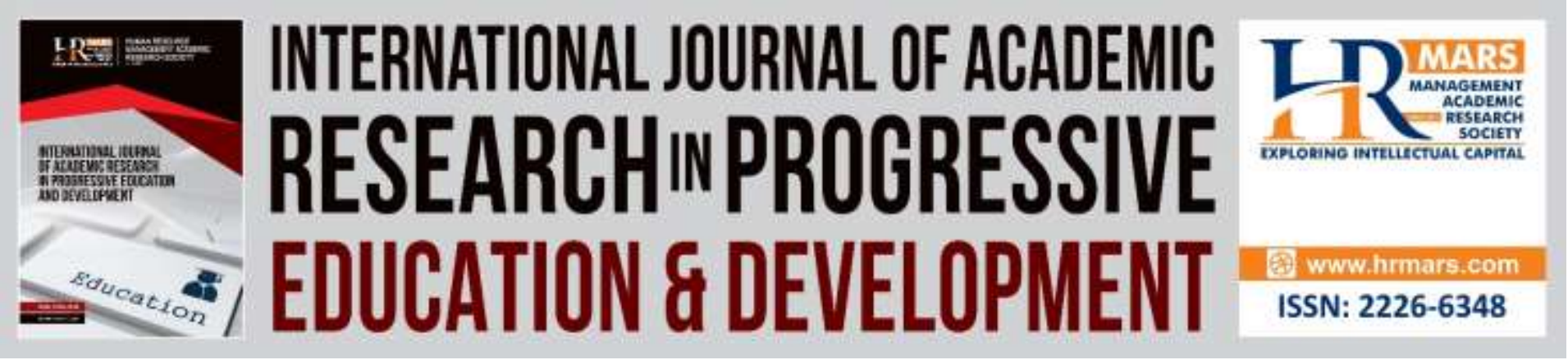

\title{
Analysis on KH. Fahmi Basya's Thoughts of Islamic Mathematics
}

\author{
Ferayanti, Rahimah Embong, Hanif Md Lateh \\ Faculty of Islamic Contemporary Studies, Universiti Sultan Zainal Abidin
}

\author{
Firdaus Khairi Abdul Kadir \\ Centre for Fundamental and Liberal Education, Universiti Malaysia Terengganu, Malaysia
}

\begin{abstract}
This article aims to explore the thoughts regarding Islamic Mathematics according to an Indonesian scholar named KH. Fahmi Basya. At the present, Islamic Mathematics is offered as one of the subjects at Islamic State University of Syarif Hidayatullah Jakarta since year 2002. This study is qualitative applying content analysis method and interviews. Data obtained from primary sources which three main works produced by this scholar namely Matematika Islam 1, Matematika Islam 2 dan Matematika Islam 3 as well as his other works. In addition, three key informants were interviewed who were $\mathrm{KH}$. Fahmi Basya, his personal manager and one expert in Islamic Mathematics. Fahmi began doing research related to the Holy Qur'an since 1972 and summarized his intellectual discoveries and findings under the discipline of Islamic mathematics in 1982. He has a strong educational background in the field of mathematics as well as deep understanding and love in the Holy Qur'an. So that, he is very concerned and creative in conducting research on the miracles of the Qur'an through mathematical approach. It is found that his writings were full of ideas relating to the phenomenon of numbers in Islam. He also highlighted the significance of learning Islamic mathematics to increase faith and confidence of a Muslim in religion and life. His thoughts regarding Islamic Mathematics are consistent with the principles of the Holy Quran and the teachings of the Prophet. The integration of mathematical concepts with Islamic worldview is essential as a holistic approach to Muslim's life in particular as well as human development and civilizational excellence in general.
\end{abstract}

Keywords: Educational Thought, Islamic Mathematics, KH. Fahmi Basya, Muslim Scholar, Holistic Education.

\section{Introduction}

The observation of the rise of Islamic civilization in the past did not deny development in education as the basis of the strength of civilization. There is no doubt that knowledge is the most important factor in determining individual happiness and the success and strength of a nation or people 
(Zakaria, 2012). For Muslims, the Qur'an and al-Sunnah should be guided in the development of community education because education in Islam is related to physical and spiritual aspects and is an integral part of the unity. Therefore, the construction of both must be balanced in order to restore the glory of Islam as it has shown in the early days of Islam.

In the Qur'an it is mentioned in Surah Mujadalah verse 11, that Allah SWT gives the highest esteem for those who believe and know. This shows that Islam is deeply rooted in the development of science (Rudi, 2015). Therefore, the world of education should include mathematics to integrate the values contained in Islam in every learning. This is because besides being able to learn mathematics in zahiriah, students can also learn the greatness of Allah through the approach of knowledge.

On the other hand, common teaching and learning subjects, in particular mathematics, do not include religious values. So the effect is that there is no relationship between mathematics and religious values, or the so-called mathematical concept of Islam. This should be the mathematical study that should link the subject in mathematics with the Qur'anic verses. Therefore, the world of education should include mathematics to integrate the values contained in Islam in every learning. This is because besides studying mathematics, students also have the opportunity to learn the greatness of God through this knowledge approach (Samsul, 2015).

In the book "Matematika dan Sains Islam Quran Pendekatan Rasional untuk Yaqin", by KH. Fahmi Basya, Islamic Mathematics is the real science inherent in the natural universe and in relation to the Qur'an. According to him again, it was time for schools, colleges and Islamic boarding schools to teach Islamic Mathematics. Taught people with logical language, taught with things they did not know, and one day hopefully this country will reach a high level (Fahmi, 2004). Islamic Mathematics according to $\mathrm{KH}$. Fahmi Basya is the mathematics that makes the Qur'an and the Sunnah of the Prophet as a backup. If ordinary maths attempt to answer environmental events using the evolutionary formula, then Islamic mathematics is able to answer the phenomenon of numbers in Islam.

In this journal discuss $\mathrm{KH}$ analysis of thought. Fahmi Basya in Islamic mathematics. With the methodology used This study is a qualitative study that applies the content analysis design. Survey data through primary source of result of authorship of $\mathrm{KH}$. Fahmi Basya, the book of "Matematika Islam 1, Matematika Islam 2 dan Matematika Islam 3". In addition, the data was also obtained from the informant interview method, KH. Fahmi Basya, her manager and field expert. The data were analyzed using a document analysis approach to the study material either primary or secondary.

\section{Integration of Mathematics in Islam}

Mathematics has a great influence on human life, being aware of or not, in fact one does not escape mathematics. But for most people it is considered that math is a very difficult and difficult subject. One of the reasons is that mathematical studies are only abstract (Anisah, 2015). If it is possible to 
INTERNATIONAL JOURNAL OF ACADEMIC RESEARCH IN PROGRESSIVE EDUCATION AND DEVELOPMENT

Vol. 8, No. 2, 2019, E-ISSN: 2226-6348 @ 2019 HRMARS

integrate values in Islam from any mathematical concept, then mathematical learning will be crucial to forming quality personalities.

Jamaa (2015) reveals that mathematics as one of the disciplines of science can be used as an approach in explaining some of the doctrines in Islamic teachings. The use of the mathematical approach here does not mean that the weak doctrine of Islamic teaching is merely to add to the Muslim belief that all science is of good value as well as enhancing faith and closeness to God.

In the journal "Integrasi Matematik dan Islam dalam Pembelajaran Matematika" states that mathematical learning needs to undergo changes in efforts to improve the quality of education so that it can improve learning outcomes to an optimal level. Therefore, efforts continue to be made for the realization of innovative learning in accordance with the development of times and technology. In addition, every lesson should benefit students both cognitive, affective, psychomotor and able to impart pure values to form the character of a country (Samsul, 2015).

Education is also expected to build the value and character of every student through religious values. Therefore, efforts should be made to create innovative learning in accordance with the religious values in the Qur'an. The integration of mathematical concepts with Islamic values is very important as a way of forming human capital. So, besides being able to learn mathematics students can also learn the greatness of God through the approach of mathematical materials (Manan, 2016).

Integrating the mathematical concept with Islamic values is very important to be applied as a way of forming a nation's character (Samsul, 2015). Thus, it is necessary to develop continuously the analysis of mathematical material by associating the verses contained in the Qur'an which is the source of all the sources of knowledge that can be taken lessons and lessons by every human being through mathematics.

\section{Islamic Mathematics}

Mathematics is the knowledge gained from the learning process. Various mathematical concepts and theories emerged and composed of real phenomena and to solve problems in real situations. It uses calculation operations based on logic, certainty and experience. The mathematical essence is related to the ideas, the structures and their relationships are arranged in logical order. Mathematics consists of observation activities, assumptions, feel, test hypotheses and seek analogies. Mathematics is also one of the important subjects in school in achieving national educational goals (Departemen Pendidikan Nasional, 2016).

Mathematics subjects should be taught to all levels of society from primary schools to equip students with logical thinking, analytical, systematic, critical, creative and able to work together. These features are required so that they can have the ability to acquire, manage and utilize information for survival in an ever-changing, uncertain, and competitive state. It also coincides with the purpose of national education that is to form students to become believers, pious, noble, 
healthy, knowledgeable, trifling, creative, self-supporting, and democratic citizens and responsible citizens (Rudi, 2015). It is also an ideal concept of Islamic education.

In the context of Islamic civilization, the development of mathematics is at least influenced by five things. The First, the encouragement of the norms derived from the Qur'an on the need to maximize efforts to meditate on the verses of God. Secondly, there is a problem that requires Muslim scientists to develop mathematics as a necessary science and is used in everyday life, especially in religious affairs. Thirdly, mathematical science is needed to build a pre-Islamic civilization and it is necessary to be developed as the area of Islamic power extends. Fourth, the excitement of science excitement from Muslim scientists. Fifth, there is political support from the ruler (Muqowim, 2012).

Modern mathematical or contemporary mathematics has a general formula that dictates from the theory of evolution and answers phenomena in the environment. While mathematical Islam is the answer to the phenomenon of life described in the Qur'an through discussions in the context of Islamic mathematics. Islamic mathematics is the mathematics that makes the Qur'an and the Sunnah as the main source. In the book 'Matematik dan Sains Islam Quran Pendekatan rasional untuk Yaqin' by KH Fahmi Basya, Islamic mathematics is the real science that exists in the universe, naturally and in relation to the Qur'an. Islamic mathematics answers the phenomenon of numbers in Islam (Fahmi, 2004).

\section{KH. Fahmi Basya's Thoughts}

KH Fahmi Basya began researching the Qur'an since 1972 and summarized the findings of the study under the sub-field of Islamic mathematics in 1982. Through the discovery, the field of mathematical Islam was one of the subjects of Islamic State University of Syarif Hidayatullah Jakarta in 2002 until To this day. KH Fahmi Basya has a strong educational background in the field of mathematics, and added his love to the Qur'an. For that reason he is very sensitive and creative to conduct research on the virtues of the Qur'an through a mathematical approach. Islamic Mathematics as a result of KH. Fahmi Basya relies on the Quran and al-Sunnah.

This Islamic mathematics course has been signed and recognized in Australia as a subject of International college which is at the time UIN Jakarta is recognized as International Uni in Australia (Fahmi, personal communication, Mei 7-8, 2017). Until now, Islamic mathematics became a subject subject in the Mathematics Department of UIN Jakarta (Rinni, personal communication, Mei 7, 2017).

In addition to being busy as a Kiai or religious figure in society, $\mathrm{KH}$. Fahmi Basya is also currently working as a researcher at the Center for Islamic Studies and Archaeological. He is recognized as an academic expert in mathematics and is active in da'wah activism (Mariyuana, personal communication, Mei 8, 2017). KH. Fahmi Basya has discovered numerous inventions that fit their expertise. Among his findings are such as the mathematical relationship between Islamic mathematics and the Qur'an that answers the phenomenon of numbers, with the aim of enhancing faith and confidence to those who read and research his findings. 
INTERNATIONAL JOURNAL OF ACADEMIC RESEARCH IN PROGRESSIVE EDUCATION AND DEVELOPMENT

Vol. 8, No. 2, 2019, E-ISSN: 2226-6348 @ 2019 HRMARS

$\mathrm{KH}$. Fahmi Basya has contributed much to his thoughts in some of his works. Some his contributions in the form of writings found by researchers is the book "One Million Phenomena, Al-Bayyinah 1 dan 2, Matematika Al-Qur'an, Matematika Islam 1 (Suatu Pendekatan Rasional Untuk Yakin), Matematika Islam 2 (Al-Qur'an 4 Dimensi), Matematika Islam 3, Borobudur dan Peninggalan Nabi Sulaiman, Bumi Itu Al-Qur'an dan Indonesia Negeri Saba".

In the book "Matematika Islam 1 sebuah pendekatan Rasional untuk Yaqin", KH. Fahmi Basya succeeded in finding new definitions and arguments relating to Islamic mathematics derived from the Qur'an. The success was achieved thanks to his outstanding diligence and precision since 1972 until now. For those who believe, the Qur'an is a guide to revealing the secrets and wisdom contained therein. There have been many scientists who discovered the miracle of the Quran from various fields, but only a few from the corners of mathematics (Komaruddin, 2014).

KH. Fahmi Basya wrote the book "Matematika Islam 2 (Al-Qur'an 4 Dimensi)", which consists of Writing, Meaning and Fact. Quran is indeed a source of knowledge that will never be exhausted to learn. The number of letters in the Qur'an is 330,733 and this number is equal to 17,407 times 19. The number 19 is equal to the number of letters in the word Bismillahirrahmaanirrahiim. This book is an extension of the book "Matematika Islam 1". In this book, KH. Fahmi Basya tried to understand the Qur'an from a science perspective that had never been mathematically untouched. He is able to elaborate the mathematical facts in the Qur'an which are found in it and all that reinforces the greatness of the Qur'an itself.

Whereas, the book "Matematika Islam 3" provides a new perspective of looking at Islamic knowledge. All forms of scientific progress have in general never contradicted what is in the Qur'an and the Sunnah. So we will be more convinced that, because Islam is all the advance of knowledge begins, and Islam is the trigger for the development of all knowledge continuously.

The book “Matematika Islam 1, Matematika Islam 2 dan Matematika Islam 3" are KH. Fahmi Basya who contributed the largest in the world of education and knowledge of the phenomenon of numbers in the Qur'an, and these three books are his thoughts as material in the subject of Islamic Mathematics at UIN Syarif Hidayatullah Jakarta (Mariyuana, personal commucation, Mei 8, 2017).

In November 2005, the Department of National Education selected the book "Matematika Islam 1 " as the best book and distributed to 6000 schools in Indonesia by the National Education Ministry in Indonesia. In 2007, the publisher Republika published the book "Matematika Islam 2", and in December 2009 published the book "Matematika Islam 3".

Through his three works in the book "Matematika Islam", after learning it can enhance the sense of trust on the Creator with the proofs of the number in the Qur'an and from the meaning and facts that exist in life associated with the Qur'anic verses and the Sunnah of the Prophet personal (Fahmi Basya, personal commucation, Mei 7, 2017). This gives a strong motivation for KH. Fahmi Basya in writing and publishing the books of "Matematika Islam 1, Matematika Islam 2 dan buku 
INTERNATIONAL JOURNAL OF ACADEMIC RESEARCH IN PROGRESSIVE EDUCATION AND DEVELOPMENT

Vol. 8, No. 2, 2019, E-ISSN: 2226-6348 @ 2019 HRMARS

Matematika Islam 3". Each book contains different content and complements the contents of the previous book.

KH Fahmi Basya's worked on the book "Matematika Islam 1, Matematika Islam 2 dan Buku Matematika Islam 3" which are divided into six chapters: (1). Quran code, (2). Axiom 19, (3). Solatum Wheel, (4). Al-Quran pillar, (5). Prayer and (6). Balok al-Quran. KH Fahmi Basya wrote this work for the young generation of Muslims to add faith and faith to Allah SAW.

The work in "Matematika Islam 1, Matematika Islam 2 dan Matematika Islam 3 ", produced by KH. Fahmi Basya based on the following five key concepts (Fahmi Basya, personal commucation, Mei 7, 2017)

1. Islamic mathematics makes the Qur'an and Sunnah as foundation.

2. Islamic mathematics give answers to the phenomenon of numbers in Islam and life based on the Quran and the Sunnah.

3. Make believers increase faith and believe in the evidence in Islamic mathematics.

4. Confident to the person given the book, the person who is writing (the person who is researching) and the person who controls the writing.

5. Writings, Reading, Meaning and facts are an essential element for people who want to understand the meaning and facts of Islamic mathematics.

According to $\mathrm{KH}$. Fahmi Basya, the main concepts distinguish the concept of Islamic Mathematical thinking with modern and contemporary mathematicians, is also different from the past of mathematical. Contemporary mathematics has a general formula that dictates rather than the theory of evolution. It is in contrast to the findings of mathematicians in medieval times whose mathematical directions are more to mathematical nature, whereas mathematical Islam answers the phenomenon of numbers in life described in the Qur'an and the Sunnah (Fahmi Basya, personal commucation, Mei 8, 2017). With strong motivation KH. Fahmi Basya in writing and researching the number in Islam is to make believers grow in their faith and believe in the evidence in Islamic mathematics.

\section{Conclusions}

From many Quranic researchers in Indonesia one of them is $\mathrm{KH}$. Fahmi Basya. With the precise scientific background in mathematics, triggering Fahmi Basya to observe the Qur'an and conducting the study of the miracle of the Koran through a mathematical approach. Fahmi Basya does not just interpret the verses of the Koran, but even more than it is to use mathematical philosophy. His thoughts are not just in the form of power points that are uploaded to the internet then called the flying book, but also contained in the form of books such as Islamic Mathematics 1, Islamic Mathematics 2, Islamic Mathematics 3, One Million Phenomena, Earth is the Quran, Borobudur \& Solomon's relics and some other books. Fahmi Basya's ongoing research makes the science of Islamic Mathematics subject in UIN Syarif Hidayatullah Islam. 
INTERNATIONAL JOURNAL OF ACADEMIC RESEARCH IN PROGRESSIVE EDUCATION AND DEVELOPMENT

Vol. 8, No. 2, 2019, E-ISSN: 2226-6348 @ 2019 HRMARS

\section{Acknowledgments}

We express our deepest gratitude to Malaysian Ministry of Education and Centre for Research Management, Innovation \& Commercialization (RIMC), UniSZA, Malaysia for supporting this publication.

\section{Corresponding Author}

Rahimah Embong, Ph.D, is Associate Professor at Department of Education, Dakwah \& Islamic Civilization, Faculty of Islamic Contemporary Studies, Universiti Sultan Zainal Abidin (UniSZA), Kampus Gong Badak, 21300 Kuala Nerus. Terengganu, Malaysia.

Email: rahimahembong@unisza.edu.my

\section{References}

Anisah, K. (2015), Mengenalkan Matematika Terintegrasi Islam Kepada Anak Sejak Dini, in Jurnal of Mathematics Education, vol.1 (1). 1-8

Departemen Pendidikan Nasional (2006), Standar Isi. Jakarta: Permendiknas no. 22

Fahmi, B. (2004). Matematik Islam dan Sains al- Qur'an, Pendekatan Rasional untuk Yakin. Jakarta: Replubika.

Fahmi, B. (2007). Matematik Islam 2: al-Qur'an 4 Dimensi. Jakarta: Replubika.

Fahmi, B. (2009). Matematik Islam 3: Jakarta: Republika.

Komaruddin, H. (2004), Kata pengantar Matematik Islam KH. Fahmi Basya, Jakarta: UIN Ciputat.

La, J. (2015). Integrasi Matematika dan Islam. (2017, July 29). Retrieved from https://syariah.iainambon.ac.id/index. php/artikel-dosen/integrasimatematika-dan-islamdr-la-jamaamhi

Manan, A. (2016). Konsep 'Arsy Menurut Fahmi Basya, Unpublished Master Thesis, UIN Sunan Kalijaga: Yogyakarta.

Muqowim (2012). Genealogi Intelektual Saintis Muslim: Sebuah Kajian Tentang Pola Pengembangan Sain dalam Islam Pada Periode Abbasiyah, Jakarta: Kementerian Agama.

Rudi, H. (2015). Aplikasi Nilai Islam Dalam Mata Pelajaran Matematik, Accessed on 2017, November 22. Retrieved from http://bdkpalembang.kemenag.go.id/aplikasi-nilai-islamdalam-mata-pelajaran-matematika/

Samsul, M. (2015) Integrasi Matematik Dan Islam Dalam Pembelajaran Matematik. Jurnal IImiah Program Studi Matematik STKIP (Sekolah Tinggi Keguruan dan IImu Pendidikan) Siliwangi Bandung, 4(2), 223-238.

Zakaria, S. (2012). Pendidikan Menurut Al-Quran dan Sunnah serta Peranannya dalam memperkasakan tamadun Ummah, Jurnal Hadhari special edition, 7-22 